\title{
Age-graded reductions in quadriceps muscle strength and peak aerobic capacity in COPD
}

\section{Reduções graduadas por idade na força muscular do quadríceps e no pico de consumo de oxigênio na DPOC}

\author{
Martijn A. Spruit', Frits M. E. Franssen', Erica P. A. Rutten', Scott S. Wagers'², Emiel F. M. Wouters',3
}

\begin{abstract}
Background: Reductions in quadriceps strength and peak aerobic capacity $\left(\dot{V} \mathrm{O}_{2}\right)$ in patients with chronic obstructive pulmonary disease (COPD) have been studied in relatively small samples over a short period. Moreover, results were not corrected for confounding variables, such as lean muscle mass, gender, and gas transfer capacity of the lungs. Objectives: To compare quadriceps muscle strength and peak $\dot{V} \mathrm{O}_{2}$ in women and men while stratifying for age and gas transfer capacity. We then corrected for lower-limb lean muscle mass to see whether and to what extent the age-graded reduction remained evident. Methods: Retrospectively, data of 374 women and 593 men with COPD were analyzed: lung function, current drug therapy, quadriceps strength, peak $\dot{V} \mathrm{O}_{2}$, lower-limb lean muscle mass, and gas transfer capacity. Results: Quadriceps strength and peak $\dot{V} \mathrm{O}_{2}$ were lower in older women and men with a gas transfer capacity of $\leq 50 \%$ predicted, also after adjustment for lower-limb lean muscle mass. Moreover, quadriceps strength and peak $\dot{V} \mathrm{O}_{2}$ were lower in older women and men with a gas transfer capacity of $\leq 50 \%$ predicted, also after adjustment for lower-limb lean muscle mass. Moreover, quadriceps strength and peak $\dot{V} \mathrm{O}_{2}$ were related to age in COPD, particularly in women and men with a gas transfer capacity of $>50 \%$ predicted. Yet, counter to our hypothesis, lower-limb lean muscle mass did not show an age-graded reduction and, in turn, could not account for the relationship of age with quadriceps strength and peak $\dot{V} \mathrm{O}_{2}$. Conclusions: It is apparent that there is an age-graded reduction in skeletal muscle function in patients with COPD. Therefore, prevention of an age-graded decline in quadriceps muscle strength and peak $\dot{V} \mathrm{O}_{2}$ may need to become an outcome of pulmonary rehabilitation of patients with COPD.
\end{abstract}

Keywords: Chronic obstructive pulmonary disease; lower-limb lean muscle mass; peak aerobic capacity; quadriceps muscle strength; isokinetic quadriceps peak torque; aging.

\section{Resumo}

Contextualização: As reduções da força do quadríceps e do pico de consumo de oxigênio $\left(\dot{V}_{\mathrm{O}_{2}}\right)$ em pacientes com doença pulmonar obstrutiva crônica (DPOC) são estudadas em amostras relativamente pequenas e por curto período de tempo. Além disso, os resultados não são corrigidos por variáveis confundidoras, como conteúdo de massa magra, gênero e capacidade de difusão pulmonar. Objetivos: Comparar a força muscular do quadríceps e o pico de $\dot{V}_{\mathrm{O}_{2}}$ em mulheres e homens estratificados por idade e capacidade de difusão pulmonar e, então, corrigir pela massa magra dos membros inferiores para verificar se e até que ponto a redução graduada por idade permaneceu evidente. Métodos: Retrospectivamente, foram analisados dados de 374 mulheres e 593 homens com DPOC, referentes a: função pulmonar, tratamento medicamentoso, força do quadríceps, pico de $\dot{V}_{\mathrm{O}_{2}}$, massa magra dos membros inferiores e capacidade de difusão pulmonar. Resultados: A força muscular do quadríceps e o pico de $\dot{V}_{\mathrm{O}_{2}}$ foram menores em idosos com capacidade de difusão pulmonar $\leq 50 \%$ do previsto, mesmo após correção pela massa magra dos membros inferiores. Além disso, a força do quadríceps e o pico de $\dot{V} \mathrm{O}_{2}$ correlacionaram-se com a idade, especialmente em homens e mulheres com capacidade de difusão $>50 \%$ do previsto. No entanto, a massa magra dos membros inferiores não demonstrou redução graduada por idade e não justificou a relação da idade com a força do

\footnotetext{
Program Development Centre, CIRO+ Rehabilitation Network*, Horn, the Netherlands

${ }^{2}$ BioSci Consulting, Maasmechelen, Belgium

${ }^{3}$ Department of Respiratory Medicine, Maastricht University Medical Centre (MUMC+), Maastricht, the Netherlands

* The CIRO+ Rehabilitation Network consists of: $\mathrm{CIRO}+$, centre of expertise for chronic organ failure in Horn, the Netherlands; Maastricht University Medical Centre (MUMC+) in Maastricht, the Netherlands; St. Jans Gasthuis in Weert, the Netherlands; Laurentius Hospital in Roermond, the Netherlands; Máxima Medical Centre in Veldhoven, the Netherlands; St. Anna Hospital in Geldrop, the Netherlands; Elkerliek Hospital in Helmond, the Netherlands.

Correspondence to: Martijn A. Spruit, Scientific Advisor at Program Development Centre, CIRO+, centre of expertise for chronic organ failure, Hornerheide 1, 6085 NM, Horn, the Netherlands, e-mail: martijnspruit@ciro-horn.nl
} 
quadríceps e o pico de $\dot{V}_{\mathrm{O}_{2}}$, contrariando a nossa hipótese. Conclusões: Aparentemente, há uma redução graduada por idade na função musculoesquelética em pacientes com DPOC. Portanto, a prevenção do declínio graduado por idade na força do quadríceps e no pico de $\dot{V} \mathrm{O}_{2}$ deveria ser um objetivo da reabilitação pulmonar em pacientes com DPOC.

Palavras-chave: doença pulmonar obstrutiva crônica; massa magra dos membros inferiores; pico de consumo de oxigênio; força muscular do quadríceps; pico de torque isocinético do quadríceps; envelhecimento.

Received: 10/03/2011 - Revised: 11/02/2011 - Accepted: 11/15/2011

\section{Introduction : $:$.}

Chronic Obstructive Pulmonary Disease (COPD) is characterized by chronic airflow limitation, as assessed by a reduced post-bronchodilator $\mathrm{FEV}_{1} / \mathrm{FVC}$ ratio $<0.7$ (where $\mathrm{FEV}_{1}$ is forced expiratory volume in the first second and FVC is forced vital capacity) $)^{1}$. The prevalence of COPD is estimated at 70 per 1000 population ${ }^{2}$. Quadriceps muscle strength and peak aerobic capacity $\left(\dot{V} \mathrm{O}_{2}\right)$ are decreased in patients with COPD compared to healthy age-matched control subjects ${ }^{3,4}$. Significant reductions in quadriceps muscle strength and peak $\dot{V} \mathrm{O}_{2}$ not only reflect a loss in physical fitness, but are also associated with increased dyspnea, fatigue, morbidity, and mortality in patients with $\mathrm{COPD}^{4-7}$.

Aging has been associated with a progressive decline in quadriceps muscle strength and peak $\dot{V}_{\mathrm{O}_{2}}$ in healthy subjects ${ }^{8,9}$. Quadriceps muscle strength and peak $\dot{V}_{2}$ have been demonstrated to decline over time in outpatients with $\mathrm{COPD}^{10-12}$. However, the reductions in quadriceps muscle strength and peak $\dot{V}_{2}$ in patients with COPD have only been studied in relatively small samples over a period of 1 to 5 years. Moreover, results were not corrected for concurrent decline in lean muscle mass. However, lean muscle mass is expected to decrease over time, in particular in the lower limbs ${ }^{13}$ and it is a well-known determinant of quadriceps muscle strength and peak $\dot{V} \mathrm{O}_{2}$ in patients with $\mathrm{COPD}^{14,15}$. In addition, gender and gas transfer capacity of the lungs have both been shown to be determinants of lean muscle mass, quadriceps muscle strength, and peak $\dot{V} \mathrm{O}_{2}$ in COPD and should therefore also be taken into consideration ${ }^{10,14,16-20}$.

We hypothesized that an age-graded reduction in quadriceps muscle strength and peak $\dot{V}_{\mathrm{O}_{2}}$ in COPD patients could largely be attributed to concurrent diminishment in lower-limb lean muscle mass (LL-LMM). In order to address this hypothesis, we retrospectively analyzed a large clinical cohort of both women and men with COPD undergoing initial evaluation for pulmonary rehabilitation ${ }^{21}$. We compared quadriceps muscle strength and peak $\dot{V}_{\mathrm{O}_{2}}$ in women and men while stratifying for age and gas transfer capacity. Indeed, gas transfer capacity is more closely related to peak $\dot{V} \mathrm{O}_{2}$ and quadriceps muscle strength than the degree of airflow limitation in patients with
COPD $^{18,22}$. We then corrected for LL-LMM to see whether and to what extent the age-graded reduction remained evident.

\section{Methods : :}

\section{Study subjects and design}

We extracted data from the records of 1963 clinically stable patients with the diagnosis of 'COPD' who were evaluated at the CIRO+, a centre of expertise for chronic organ failure in Horn (the Netherlands) $)^{21}$ between January 1, 2005 and January 1, 2010. Of these records, 967 met the following inclusion criteria: presence of all necessary data, a post-bronchodilator FEV1/ FVC ratio $\leq 0.70$, the transfer factor for carbon monoxide $\left(\mathrm{D}_{\mathrm{L}} \mathrm{CO}\right)$, peak $\dot{V}_{\mathrm{O}_{2}}$, isokinetic quadriceps peak torque, LL-LMM, and no repeat admission for the same patient. All patients with long-term oxygen therapy were excluded from the analyses due to the lack of a determined peak $\dot{V} \mathrm{O}_{2}$. These retrospective analyses are institutional review board-exempt due to the use of de-identified, pre-existing data.

All patients were referred by chest physicians from multiple hospitals in 2 southeastern provinces in the Netherlands for a comprehensive pulmonary rehabilitation program ${ }^{21}$. Patients used short-acting $\beta_{2}$ agonist (33\%); short-acting anticholinergic (15\%); combination of short-acting $\beta_{2}$ agonist and short-acting anticholinergic in one device (20\%); long-acting $\beta_{2}$ agonist (21\%); long-acting anticholinergic (69\%); inhalation corticosteroids (14\%); long-acting $\beta_{2}$ agonist and inhalation steroids in one device (71\%); theophylline (14\%); $36 \% \mathrm{~N}$-acetyl cystein (34\%); maintenance oral steroids (13\%); or a combination thereof.

\section{Methods}

As part of a 3-day routine baseline assessment ${ }^{21}$ patients underwent, amongst other tests, a symptom-limited cardiopulmonary incremental cycle test ( +10 watts per minute) where peak $\dot{V} \mathrm{O}_{2}$ was determined in accordance with the guidelines of the American Thoracic Society and the American College of Chest Physicians ${ }^{23}$. Routine post-bronchodilator spirometry, $\mathrm{D}_{\mathrm{L}} \mathrm{CO}$ and arterial blood gas analysis were performed according 
to international recommendations ${ }^{24,25}$. In addition, patients underwent physical examination by a chest physician (including assessment of body weight and height) and medical history as described before ${ }^{26}$. Finally, single-leg isokinetic quadriceps peak torque and LL-LMM were determined using a BIODEX computerized dynamometer and a Lunar Prodigy dual-energy $\mathrm{x}$-ray absorptiometry scan, respectively ${ }^{13,15}$.

\section{Statistical analyses}

All statistical analyses were carried out using GraphPad Prism 4.03 and SPSS 17.0. Data are presented as mean and standard deviation or proportion, as appropriate. Patients were stratified by gender and age (age group 1: $\leq 50$ years; age group 2: 51 to 60 years; age group 3: 61 to 70 years; or age group 4: $\geq 71$ years). Moreover, due to the strong correlation in COPD between peak $\dot{V} \mathrm{O}_{2}$ and $\mathrm{D}_{\mathrm{L}} \mathrm{CO}^{22}$ and $\mathrm{D}_{\mathrm{L}} \mathrm{CO}$ and quadriceps muscle strength ${ }^{18}$, patients were stratified based on the $\mathrm{D}_{\mathrm{L}} \mathrm{CO}: \leq 50 \%$ predicted and $>50 \%$ predicted ${ }^{27}$. Please see Table E1 of the online depository for details on the number of patients per stratum (link to online depository: http://www. ciro-horn.nl/wordpress/wp-content/uploads/2011/11/ONLINESUPPLEMENT-Age-graded-reductions-in-quadriceps-musclestrength-and-peak-aerobic-capacity-in-COPD.pdf).

A two-tailed unpaired t-test was used to determine differences between women and men and between the $\mathrm{D}_{\mathrm{L}} \mathrm{CO}$ strata. Age-graded differences were assessed using a one-way analysis of variances. Fisher's least significant differences test was used as post-hoc test because of an unequal group size. Stepwise multiple regression analyses were done to assess independent contributors to the variance in isokinetic quadriceps peak torque and peak $\dot{\mathrm{VO}}_{2}$. A priori, a two-sided level of significance was set at $\mathrm{p} \leq 0.05$.

\section{Results $: \because$.}

\section{Characteristics}

COPD severity ranged from mild to very severe. The average resting blood gas values and body mass index were normal. About half of the patients were current smokers (Table 1). LL-LMM, isokinetic quadriceps peak torque, and peak $\dot{V}_{2}$ were clearly reduced compared to published data from healthy elderly subjects ${ }^{15,17,28}$. At peak exercise, patients generally had little ventilatory reserve and rather high Borg symptom scores for dyspnea and fatigue (Table 2).

\section{Gender differences}

On average, the male COPD patients were older, had a worse pulmonary function and a higher score on the Charlson co-morbidity index compared to the female patients. Moreover, men had a significantly higher LL-LMM

Table 1. Characteristics.

\begin{tabular}{|c|c|c|c|c|}
\hline & $\begin{array}{l}\text { Whole group } \\
\qquad(n=967)\end{array}$ & $\begin{array}{l}\text { Women } \\
(n=374)\end{array}$ & $\begin{array}{c}\text { Men } \\
(n=593)\end{array}$ & $\begin{array}{c}\text { p-value } \\
\text { (women vs. men) }\end{array}$ \\
\hline Age, years & $63.6(9.8)$ & $59.9(9.7)$ & $66.0(9.2)$ & 0.000 \\
\hline $\mathrm{FEV}_{1}$, liters & $1.37(0.55)$ & $1.23(0.48)$ & $1.46(0.57)$ & 0.000 \\
\hline $\mathrm{FEV}_{1}, \%$ predicted & $50.7(18.1)$ & $54.1(18.8)$ & $48.6(17.3)$ & 0.000 \\
\hline $\mathrm{FEV}_{1} / \mathrm{IVC}, \%$ & $41.2(12.8)$ & $43.9(12.9)$ & $39.6(12.5)$ & 0.000 \\
\hline GOLD stage I/II, \% & 47.5 & 56.1 & 42.0 & 0.001 \\
\hline GOLD stage III, \% & 38.1 & 34.0 & 40.6 & \\
\hline GOLD stage IV, \% & 14.5 & 9.9 & 17.4 & \\
\hline $\mathrm{D}_{L} \mathrm{CO}, \%$ predicted & $54.6(18.6)$ & $51.9(17.4)$ & $56.3(19.1)$ & 0.000 \\
\hline$D_{1} \mathrm{CO} \leq 50 \%$ predicted, $\%$ & 45.6 & 50.0 & 42.8 & 0.000 \\
\hline $\mathrm{PaO}_{2}, \mathrm{kPa}$ & $9.6(1.2)$ & $9.6(1.2)$ & $9.6(1.3)$ & 0.290 \\
\hline $\mathrm{PaCO}_{2}, \mathrm{kPa}$ & $5.2(0.6)$ & $5.2(0.6)$ & $5.2(0.6)$ & 0.567 \\
\hline $\mathrm{SaO}_{2}, \%$ & $94.8(2.3)$ & $95.0(2.1)$ & $94.6(2.4)$ & 0.022 \\
\hline $\mathrm{HbCO} \geq 2 \%, \%$ & 45.7 & 54.3 & 40.3 & 0.001 \\
\hline Body weight, kg & $71.5(14.7)$ & $65.2(13.7)$ & $75.5(13.9)$ & 0.000 \\
\hline $\mathrm{BMI}, \mathrm{kg} / \mathrm{m}^{2}$ & $25.2(4.6)$ & $24.9(5.0)$ & $25.3(4.3)$ & 0.248 \\
\hline Lower-limb LMM, kg & $14.6(3.1)$ & $12.0(1.8)$ & $16.3(2.5)$ & 0.000 \\
\hline Charlson index, points & $1.7(1.1)$ & $1.4(0.9)$ & $1.8(1.2)$ & 0.000 \\
\hline Charlson index >1 point, \% & 38.2 & 25.1 & 46.4 & 0.000 \\
\hline
\end{tabular}

Values presented as mean (standard deviation) or as proportion, as appropriate. FEV1: forced expiratory volume in the first second; FM: fat mass; IVC: inspiratory vital capacity; LMM: lean muscle mass; RV: residual volume; TLC: total lung capacity; $\mathrm{D}_{1} \mathrm{CO}$ : carbon monoxide transfer factor; \%: percentage; $\mathrm{PaO}_{2}$ : arterial oxygen tension; $\mathrm{PaCO}_{2}$ : arterial carbon monoxide tension: $\mathrm{SaO}_{2}$ : arterial oxygen saturation; $\mathrm{kPa}$ : kilo Pascal; $\mathrm{BMl}$ : body mass index; m: meters. 
Table 2. Peak exercise performance and quadriceps muscle strength.

\begin{tabular}{|c|c|c|c|c|}
\hline & $\begin{array}{l}\text { Whole group } \\
\quad(n=967)\end{array}$ & $\begin{array}{l}\text { Women } \\
(n=374)\end{array}$ & $\begin{array}{c}\text { Men } \\
(n=593)\end{array}$ & $\begin{array}{c}p \text {-value } \\
\text { (women vs. men) }\end{array}$ \\
\hline Peak $\dot{V} \mathrm{O}_{2}, \mathrm{ml} / \mathrm{min}$ & $1138(347)$ & $1008(258)$ & $1220(370)$ & 0.000 \\
\hline Peak $\dot{V} O_{2}, \mathrm{ml} / \mathrm{min} / \mathrm{kg} \mathrm{BW}$ & $16.1(4.3)$ & $15.8(4.1)$ & $16.3(4.4)$ & 0.110 \\
\hline Metabolic equivalents & $4.6(1.2)$ & $4.5(1.2)$ & $4.7(1.3)$ & 0.110 \\
\hline Peak $\dot{V} O_{2}, \mathrm{ml} / \mathrm{min} / \mathrm{kg} \mathrm{LL}-\mathrm{LMM}$ & $78.6(19.5)$ & $84.5(18.8)$ & $74.8(19.1)$ & 0.000 \\
\hline Peak power output, watts & $74.5(30.6)$ & $65.9(25.3)$ & $80.0(32.3)$ & 0.000 \\
\hline Peak VE, liters & $45.4(15.1)$ & $39.9(12.0)$ & $48.9(15.8)$ & 0.000 \\
\hline Peak VE, \% MVV & $86.9(24.2)$ & $86.0(24.9)$ & $87.5(23.8)$ & 0.356 \\
\hline Peak HR, bpm & $126.9(21.4)$ & $130.9(21.7)$ & $124.3(21.0)$ & 0.000 \\
\hline Peak HR, \% HRmax & $81.1(12.6)$ & $81.7(12.7)$ & $80.7(12.5)$ & 0.202 \\
\hline Oxygen pulse, ml/min/bpm & $9.1(2.5)$ & $7.8(1.9)$ & $9.8(2.6)$ & 0.000 \\
\hline Peak $\mathrm{SaO}_{2}, \%$ & $91.3(4.3)$ & $91.8(4.0)$ & $91.0(4.4)$ & 0.009 \\
\hline$\Delta \mathrm{SaO}_{2}, \%$ & $-3.6(3.7)$ & $-3.4(3.6)$ & $-3.7(3.8)$ & 0.195 \\
\hline Borg score DYS, points & $7.0(2.2)$ & $7.1(2.1)$ & $6.9(2.2)$ & 0.085 \\
\hline Borg score FAT, points & $5.6(2.6)$ & $5.7(2.6)$ & $5.6(2.0)$ & 0.351 \\
\hline IQPT, Nm & $90.1(32.6)$ & $72.0(21.6)$ & $101.5(33.2)$ & 0.000 \\
\hline IQPT, Nm/kg LL-LMM ${ }^{\S}$ & $12.3(3.2)$ & $12.1(3.1)$ & $12.4(3.3)$ & 0.125 \\
\hline
\end{tabular}

Values presented as mean (standard error). $\dot{V} 0_{2}: \dot{V} O_{2}$; ml/min: milliliter per minute; kg: kilogram; BW: body weight; LMM: lean muscle mass; LL: lower-limbs; bpm: beats per minute; $\%$ : percentage; MVV: maximal voluntary ventilation; HRmax: calculated maximum heart rate (220-age in years); $\mathrm{SaO}_{2}$ : transcutaneous oxygen saturation; $\triangle$ : change; DYS: dyspnea; FAT: fatigue; IQPT: isokinetic quadriceps peak torque; Nm: Newton-meter; $\S$ : IQPT of the quadriceps muscle has been assessed single-legged, therefore lower-limb lean muscle mass has been divided by 2 .

(mean difference: $4.3 \mathrm{~kg}, \mathrm{p}<0.01$ ), isokinetic quadriceps peak torque (mean difference: 29.5 Newton-meter, $\mathrm{p}<0.01$ ), and absolute peak $\dot{V} \mathrm{O}_{2}$ (mean difference: $211 \mathrm{ml} / \mathrm{min}, \mathrm{p}<0.01$ ), while the women had a significantly higher peak $\dot{V}_{\mathrm{O}_{2}}$ after adjustment for LL-LMM (mean difference: $9.8 \mathrm{ml} / \mathrm{min} / \mathrm{kg}$ LL-LMM, p <0.01). Non-significant gender-related differences were found for peak ventilation (\% maximal voluntary ventilation), peak heart rate (\% calculated maximum heart rate), Borg symptom scores, and isokinetic quadriceps peak torque after adjustment for LL-LMM (Table 2).

\section{Gender-related differences after stratification for age}

As expected, men had a significantly higher mean LLLMM, isokinetic quadriceps peak torque, and absolute peak $\dot{V} \mathrm{O}_{2}$ compared to women also after stratification for age (Figures 1a to 1c). Moreover, men of age $\geq 51$ years had a significantly higher mean isokinetic quadriceps peak torque after adjustment for LL-LMM compared to women (Figure 1d). In contrast, gender-related differences in absolute peak $\dot{V} \mathrm{O}_{2}$ disappeared after adjustment for LLLMM. Indeed, mean peak $\dot{V}_{\mathrm{O}_{2}}$ adjusted for LL-LMM was significantly higher in women of age $\geq 51$ years compared to male peers (Figure 1e). See Table E2 of the online depository for more details on mean differences between groups and p-values.

\section{Age-related difference after stratification for gender}

Generally, patients of age $\leq 50$ years had a higher isokinetic quadriceps peak torque and peak $\dot{V}_{2}$ (absolute values and after adjustment for LL-LMM) compared to older patients, irrespective of gender (Figure 1). Male patients with age $\geq 71$ years had the lowest LL-LMM compared to younger male patients. No age-graded reductions were found in LL-LMM in female patients (Figure 1a). See Table E3 of the online depository for more details on mean differences between groups and p-values.

\section{$D_{L}$ CO-related differences after stratification for gender and age}

After stratification for age, women with a $\mathrm{D}_{\mathrm{L}} \mathrm{CO}>50 \%$ predicted had a higher mean LL-LMM (in women 51 to 70 years of age; Figure 2a), isokinetic quadriceps peak torque (in women of age $\leq 50$ years; Figure $2 \mathrm{~b}$ ) and absolute peak $\dot{V}_{\mathrm{O}_{2}}$ (Figure 2c) compared to women with a $\mathrm{D}_{\mathrm{L}} \mathrm{CO} \leq 50 \%$ predicted. Moreover, peak $\dot{V} \mathrm{O}_{2}$ remained different between both subsets after adjustment for LL-LMM (Figure 3b). Isokinetic quadriceps peak torque adjusted for LL-LMM was not different between $\mathrm{D}_{\mathrm{L}} \mathrm{CO}$ strata (Figure 3a). See Table E4 of the online depository for more details on mean differences between groups and p-values.

A similar pattern was observed in the male patients after stratification for age and $\mathrm{D}_{\mathrm{L}} \mathrm{CO}$. Indeed, male patients with a 

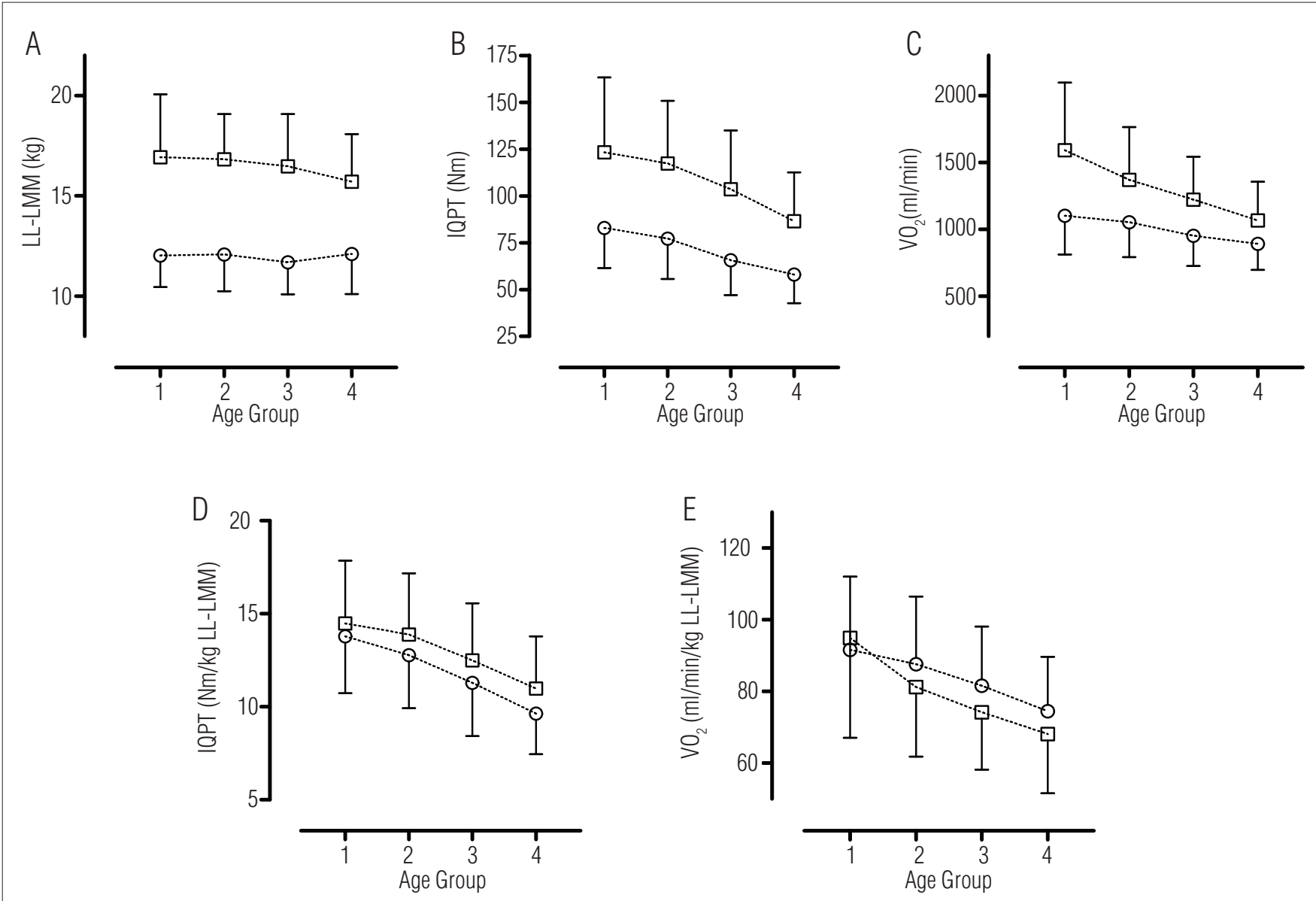

Lower-limb lean muscle mass (LL-LMM, kg; Figure 1a), isokinetic quadriceps peak torque (IQPT, Newton-meter, Nm; Figure 1b), and peak aerobic capacity $\left(\dot{V} \mathrm{O}_{2}\right.$, ml/min; Figure 1c) after stratification for age (group 1: $\leq 50$ years; group 2: 51 to 60 years; group 3: 61 to 70 years; group 4: $\geq 71$ years) and gender (women: open circles; men: open squares). See Table E2 in the online supplement for more details. Isokinetic quadriceps peak torque adjusted for LL-LMM (IQPT/LL-LMM, Nm/kg; Figure 1d) and peak $\dot{V} O_{2}$ adjusted for LL-LMM ( $\dot{V} O_{2} /$ LL-LMM, ml/min/kg; Figure 1e) after stratification for age and gender (women: open circles; men: open squares). See Table E2 in the online supplement for more details.

Figure 1. Lower-limb lean muscle mass, isokinetic quadriceps peak torque, and peak aerobic capacity after stratification for age in 374 women and 593 men with COPD.

$\mathrm{D}_{\mathrm{L}} \mathrm{CO}>50 \%$ predicted had a higher mean LL-LMM (in men of age $\geq 51$ years; Figure $2 \mathrm{~d}$ ), isokinetic peak torque (in men $\leq 70$ years of age; Figure 2e) and absolute peak $\dot{V} \mathrm{O}_{2}$ (Figure 2f) compared to male patients with a $\mathrm{D}_{\mathrm{L}} \mathrm{CO} \leq 50 \%$ predicted. These $\mathrm{D}_{\mathrm{L}} \mathrm{CO}$-related differences remained after adjustment for LLLMM, in particular for peak $\dot{V} \mathrm{O}_{2}$ (Figures 3c and 3d). See Table E5 of the online depository for more details on mean differences between groups and p-values.

\section{Age-related differences after stratification for gender and $\mathrm{D}_{\mathrm{L}} \mathrm{CO}$}

Women with a $\mathrm{D}_{\mathrm{L}} \mathrm{CO} \leq 50 \%$ predicted showed an agegraded reduction in isokinetic quadriceps peak torque (Figure 2b) and peak $\dot{V} \mathrm{O}_{2}$ (Figure 2c). These age-graded reductions remained after adjustment for LL-LMM (Figures 3a and $3 \mathrm{~b})$. The age-graded reductions in isokinetic quadriceps peak torque (Figure 2b) and peak $\dot{V} \mathrm{O}_{2}$ (Figure 2c) were even more explicit in the women with a $\mathrm{D}_{\mathrm{L}} \mathrm{CO}>50 \%$ predicted. LL-LMM did not show an age-graded reduction in either $\mathrm{D}_{\mathrm{L}} \mathrm{CO}$ group (Figure 2a). A similar pattern was observed for the male patients after stratification for $\mathrm{D}_{\mathrm{L}} \mathrm{CO}$ (Figures $2 \mathrm{~d}$, 2e, 2f, 3c, and 3d). See Table E6 of the online depository for more details on mean differences between groups and p-values.

\section{Stepwise multiple regression model}

A stepwise multiple regression analysis ascertained LL-LLM, age, peak $\dot{V} \mathrm{O}_{2}$, and gender to be significant determinants of isokinetic quadriceps peak torque. This model explained $56.4 \%$ of the variance in isokinetic quadriceps peak torque $(\mathrm{p}=0.01) . \mathrm{D}_{\mathrm{L}} \mathrm{CO}(\mathrm{p}=0.73), \mathrm{FEV}_{1}(\mathrm{p}=0.16)$, and BMI ( $\mathrm{p}=0.07)$ did not contribute to the model. 


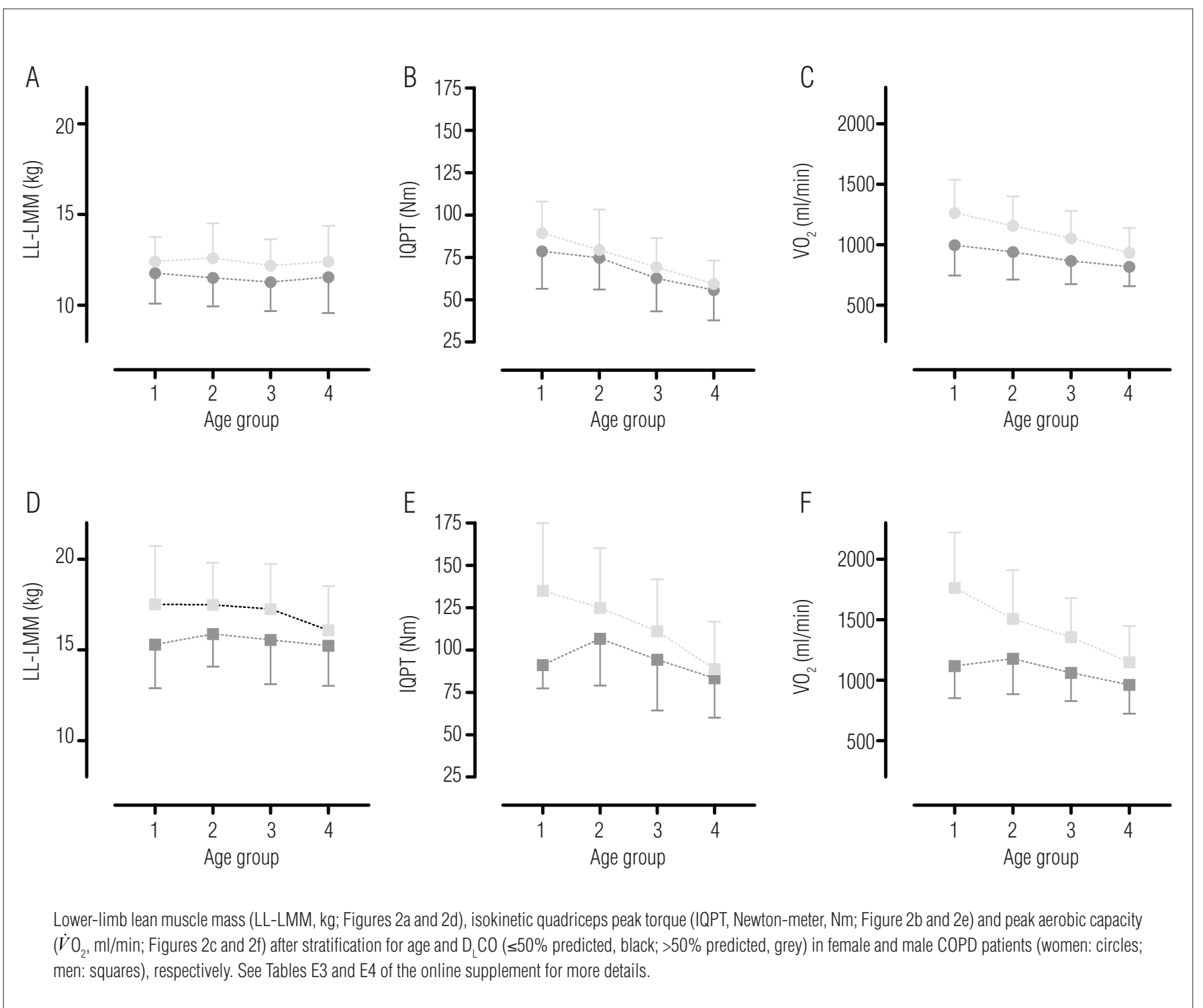

Figure 2. Lower-limb lean muscle mass, isokinetic quadriceps peak torque, and peak aerobic capacity after adjustment for age and $D_{L} \mathrm{CO}$ in women and men with COPD.

A stepwise multiple regression analysis ascertained isokinetic quadriceps peak torque, $\mathrm{D}_{\mathrm{L}} \mathrm{CO}, \mathrm{FEV}$, BMI, age and LLLMM to be significant determinants of peak $\dot{V}_{\mathrm{O}_{2}}$. This model explained $59.3 \%$ of the variance in peak $\dot{V}_{2}(\mathrm{p}=0.01)$. Gender did not contribute to the model $(\mathrm{p}=0.22)$.

\section{Discussion $: \because$.}

As we expected, quadriceps muscle strength and peak $\dot{V}_{\mathrm{O}_{2}}$ were related to age in patients with COPD, particularly in those with $\mathrm{D}_{\mathrm{L}} \mathrm{CO}>50 \%$ predicted. Yet, counter to our hypothesis LLLMM did not account for the relationship of age with quadriceps muscle strength and peak $\dot{V}_{\mathrm{O}_{2}}$. Indeed, an age-graded reduction in LL-LMM was only present in the older men with a $\mathrm{D}_{\mathrm{L}} \mathrm{CO}>50 \%$ predicted. The results of this study suggest the presence of age-related qualitative abnormalities in lower-limb muscles in patients with COPD (i.e. a decrease in isokinetic peak torque per unit weight of lower-limb lean muscle mass and/or a decrease in peak $\dot{V}_{2}$ per unit weight of lower-limb lean muscle mass).

An age-related decline in quadriceps muscle strength and peak $\dot{V} \mathrm{O}_{2}$ is well established in healthy subjects and in cardiac patients ${ }^{8,929}$. Moreover, small but significant reductions in quadriceps muscle strength ${ }^{10}$ and peak $\dot{V} \mathrm{O}_{2}{ }^{11,12}$ were found in (mostly male) COPD patients over a 1 to 5 year period, respectively. To the best of our knowledge, this is the first study to show an agegraded reduction in quadriceps muscle strength and peak $\dot{V} \mathrm{O}_{2}$ in patients with COPD after correction for possible confounding factors, such as gender, LL-LMM, and $\mathrm{D}_{\mathrm{L}} \mathrm{CO}$. More importantly 

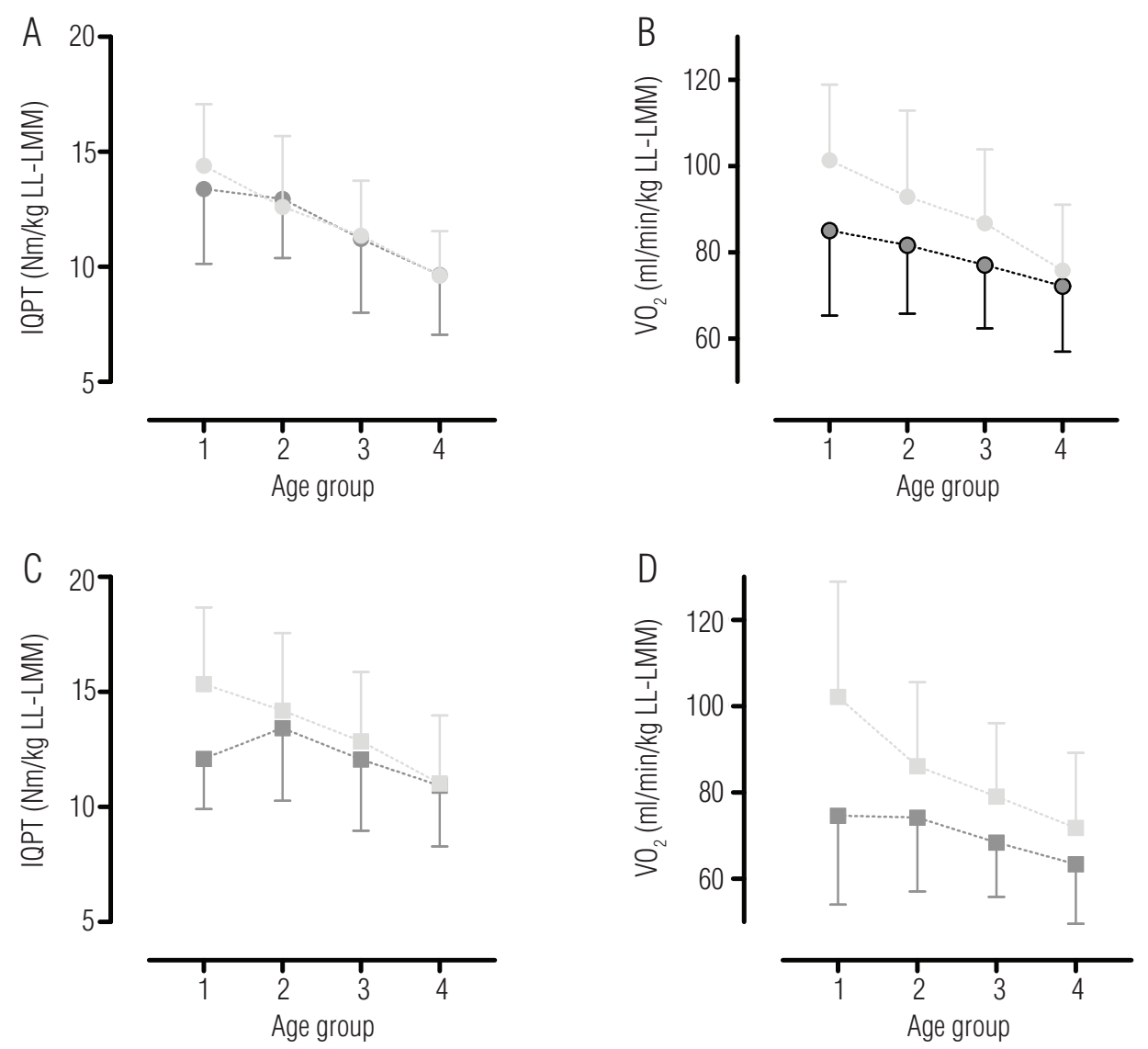

Isokinetic quadriceps peak torque adjusted for LL-LMM (IQPT/LL-LMM, Nm/kg; Figures 3a and 3c) and peak $\dot{V} \mathrm{O}_{2}$ adjusted for LL-LMM ( $\dot{V} \mathrm{O}_{2} / \mathrm{LL}-\mathrm{LMM}, \mathrm{ml} / \mathrm{min} / \mathrm{kg}$; Figures $3 \mathrm{~b}$ and $3 \mathrm{~d}$ ) after stratification for age and $\mathrm{D}_{\mathrm{L}} \mathrm{CO}(\leq 50 \%$ predicted, black; $>50 \%$ predicted, grey) in female and male COPD patients (women: circles; men: squares), respectively. See Tables E3 and E4 of the online supplement for more details.

Figure 3. Quadriceps muscle strength and peak aerobic capacity after adjustment for age, lower-limb lean muscle mass, and D,CO in women and men with COPD.

this study corroborates the previously identified decrease in lower-limb muscle function in patients with $\mathrm{COPD}^{3,16}$. Moreover, our results also highlight age-graded differences between men and women, which also parallels previous findings ${ }^{30}$.

Lower-limb muscle weakness can occur without an overt loss of LL-LMM in patients with COPD suggesting the presence of qualitative skeletal muscle abnormalities ${ }^{16}$, particularly in women ${ }^{3}$. The present findings are in line: skeletal muscle function can decrease without a decrease in LL-LMM in patients with COPD, in particular in women (Table E2). In healthy elderly subjects, gender differences exist in the contractile properties of lower-limb muscles. Indeed, type I and IIA fibers from older healthy men were generally stronger than similar fibers from older women even after adjusting for size ${ }^{31}$. Whether and to what extent gender differences in muscle contractile properties are also present in COPD remains currently unknown ${ }^{32}$.

There are several factors that may explain the overt loss in peak $\dot{V} \mathrm{O}_{2}$ (absolute and corrected for LL-LMM) in
COPD. Patients with COPD have a significantly lower mitochondrial density ${ }^{33}$ and activity ${ }^{34}$, as well as a lower oxidative enzyme activity ${ }^{35}$ and a lower mechanical efficiency ${ }^{36}$. There are also fewer capillaries per muscle fiber in patients with COPD. Lastly, there are more type II muscle fibers in patients with COPD compared to healthy age-matched control subjects ${ }^{37}$. A worsening of the above-mentioned intramuscular manifestations over time may explain the age-related differences in peak $\dot{V} \mathrm{O}_{2}$. However, most of these intramuscular changes have been identified in small crosssectional studies of mostly men, focusing mainly on the vastus lateralis muscle and GOLD stages 3 and 4. Coupled with our results, these mechanistic insights underline the importance of continued research on this phenomenon of loss of lower-limb muscle $\dot{V} \mathrm{O}_{2}$. Indeed, there is great potential for identifying new therapeutic targets ${ }^{38}$.

Significant differences in lower-limb muscle function were found in female (Figures $3 \mathrm{a}$ and $3 \mathrm{~b}$ ) and male COPD patients 
(Figures $3 \mathrm{c}$ and $3 \mathrm{~d}$ ) after stratification for $\mathrm{D}_{\mathrm{L}} \mathrm{CO}$. This seems to be in line with previous findings of Amann et al. ${ }^{39}$, who reported that the high susceptibility to lower-limb muscle fatigue in patients with COPD is in part attributable to insufficient oxygen transport as a consequence of exaggerated arterial hypoxemia and/or excessive respiratory muscle work. Moreover, quadriceps muscle strength was positively related to $\mathrm{D}_{\mathrm{L}} \mathrm{CO}$ in patients with $\mathrm{COPD}^{18}$.

Age-related reductions in LL-LMM have been reported in healthy women and $\operatorname{men}^{17}$. Hopkinson at al. ${ }^{10}$ reported a non-significant decline of 0.2 kilogram in fat-free mass during a 1-year follow-up period in $64 \mathrm{COPD}$ patients ${ }^{10}$. Also in the current cross-sectional analyses no age-graded reductions in LL-LMM were found, except for the older male COPD patients with a $\mathrm{D}_{\mathrm{L}} \mathrm{CO}>50 \%$ predicted (Figure $3 \mathrm{~d}$ and Table E6 of the online supplement). It remains difficult to understand the lack of age-graded reductions in LL-LMM in patients with COPD.

The external validity of the present findings is limited to COPD patients without long-term oxygen therapy. Thus the present data should not be uncritically applied to GOLD IV patients with long-term oxygen therapy. Obviously, a major limitation of the present analysis is the lack of a healthy control group and the lack of information about daily physical activity levels. However, quadriceps muscle strength and peak $\dot{V} \mathrm{O}_{2}$ have been found to decline over time in healthy subjects ${ }^{9,30}$. Moreover, the influence of daily physical inactivity on an age-related decline in peak $\dot{V} \mathrm{O}_{2}$ remains a matter of debate ${ }^{8,30}$. Patients with COPD have a reduced level of daily physical activity, which is present even in the earliest stages of the disease ${ }^{40}$. It is for this reason that it is not very surprising that quadriceps muscle strength and peak $\dot{V} \mathrm{O}_{2}$ in patients with COPD is very low compared to healthy subjects ${ }^{8,17,30}$ and not unlike that in patients entering cardiac rehabilitation ${ }^{29}$. Accordingly, the majority of subjects with COPD in our study (98.8\%) had a metabolic equivalent below 8 , which is an identified risk factor of death from any cause ${ }^{6}$. In addition, an age-related decline in peak $\dot{V} \mathrm{O}_{2}$ can explain, at least in part, the development of disability in patients with $\mathrm{COPD}^{41}$. Indeed, GOLD stage II patients use a higher proportion of their (reduced) peak $\dot{V} \mathrm{O}_{2}$ compared to healthy elderly subjects during the performance of simple, self-paced domestic activities of daily living ${ }^{4}$. Finally, large longitudinal studies are needed to corroborate the current findings.

In summary, we have found that lower-limb muscle quality is lower in older patients with COPD, also after stratification for gender and gas transfer. Therefore, prevention of an age-graded decline in quadriceps muscle strength and peak $\dot{V} \mathrm{O}_{2}$ may need to become an outcome of the management of patients with COPD.

\section{References}

1 Rabe KF, Hurd S, Anzueto A, Barnes PJ, Buist SA, Calverley P, et al. Global strategy for the diagnosis, management, and prevention of chronic obstructive pulmonary disease: GOLD executive summary. Am J Respir Crit Care Med. 2007;176:532-55

2 Celli BR, MacNee W; ATS/ERS Task Force. Standards for the diagnosis and treatment of patients with COPD: a summary of the ATS/ERS position paper. Eur Respir J. 2004;23(6):932-46

3 Seymour JM, Spruit MA, Hopkinson NS, Natanek SA, Man WD, Jackson A, et al. The prevalence of quadriceps weakness in COPD and the relationship with disease severity. Eur Respir J. 2010;36(1):81-8

4 Vaes AW, Wouters EF, Franssen FM, Uszko-Lencer NH, Stakenborg KH, Westro M, et al. Taskrelated oxygen uptake during domestic activities of daily life in patients with COPD and healthy elderly subjects. Chest. 2011;140(4):970-9

5 Decramer M, Gosselink R, Troosters T, Verschulren M, Evers G. Muscle weakness is related to utilization of health care resources in COPD patients. Eur Respir J. 1997;10(2):417-23.

6 Myers J, Prakash M, Froelicher V, Do D, Partington S, Atwood JE. Exercise capacity and mortality among men referred for exercise testing. N Engl J Med. 2002;346(11):793-801.

7 Swallow EB, Reyes D, Hopkinson NS, Man WD, Porcher R, Cetti EJ, et al. Quadriceps strength predicts mortality in patients with moderate to severe chronic obstructive pulmonary disease. Thorax. 2007;62(2):115-20.

8 Fleg JL, Morrell CH, Bos AG, Brant LJ, Talbot LA, Wright JG, et al. Accelerated Iongitudinal decline of aerobic capacity in healthy older adults. Circulation. 2005;112(5):674-82.

9 Frontera WR, Hughes VA, Fielding RA, Fiatarone MA, Evans WJ, Roubenoff R. Aging of skeletal muscle: a 12-yr longitudinal study. J Appl Physiol. 2000;88(4):1321-6.

10 Hopkinson NS, Tennant RC, Dayer MJ, Swallow EB, Hansel TT, Moxham J, et al. A prospective study of decline in fat free mass and skeletal muscle strength in chronic obstructive pulmonary disease. Respir Res. 2007;8:25.

11 Oga T, Nishimura K, Tsukino M, Sato S, Hajiro T, Mishima M. Exercise capacity deterioration in patients with COPD: Iongitudinal evaluation over 5 years. Chest. 2005;128(1):62-9

12 Oga T, Nishimura K, Tsukino M, Sato S, Hajiro T, Mishima M, et al. Longitudinal deteriorations in patient reported outcomes in patients with COPD. Respir Med. 2007;101(1):146-53.

13 Engelen MP, Schols AM, Does JD, Wouters EF. Skeletal muscle weakness is associated with wasting of extremity fat-free mass but not with airflow obstruction in patients with chronic obstructive pulmonary disease. Am J Clin Nutr. 2000;71(3):733-8.

14 Baarends EM, Schols AM, Mostert R, Wouters EF. Peak exercise response in relation to tissue depletion in patients with chronic obstructive pulmonary disease. Eur Respir J. 1997;10(12):2807-13.

15 Franssen FM, Broekhuizen R, Janssen PP, Wouters EF, Schols AM. Limb muscle dysfunction in COPD: effects of muscle wasting and exercise training. Med Sci Sports Exerc. 2005;37(1):2-9.

16 Bernard S, LeBlanc P, Whittom F, Carrier G, Jobin J, Belleau R, et al. Peripheral muscle weakness in patients with chronic obstructive pulmonary disease. Am J Respir Crit Care Med. 1998;158(2):629-34.

17 Neder JA, Lerario MC, Castro ML, Sachs A, Nery LE. Peak V02 correction for fat-free mass estimated by anthropometry and DEXA. Med Sci Sports Exerc. 2001;33(11):1968-75

18 Spruit MA, Gosselink R, Troosters T, Kasran A, Gayan-Ramirez G, Bogaerts P, et al. Muscle force during an acute exacerbation in hospitalised patients with COPD and its relationship with CXCL8 and IGF-I. Thorax. 2003;58(9):752-6.

19 Eid AA, Ionescu AA, Nixon LS, Lewis-Jenkins V, Matthews SB, Griffiths TL, et al. Inflammatory response and body composition in chronic obstructive pulmonary disease. Am J Respir Crit Care Med. 2001;164(8 Pt 1):1414-8

20 Pinto-Plata VM, Celli-Cruz RA, Vassaux C, Torre-Bouscoulet L, Mendes A, Rassulo J, et al Differences in cardiopulmonary exercise test results by American Thoracic Society/European Respiratory Society-Global Initiative for Chronic Obstructive Lung Disease stage categories and gender. Chest. 2007;132(4):1204-11

21 Spruit MA, Vanderhoven-Augustin I, Janssen PP, Wouters EF. Integration of pulmonary rehabilitation in COPD. Lancet. 2008;371(9606):12-3. 
22 Gosselink R, Troosters T, Decramer M. Peripheral muscle weakness contributes to exercise limitation in COPD. Am J Respir Crit Care Med. 1996;153(3):976-80

23 American Thoracic Society; American College of Chest Physicians. ATS/ACCP Statement on cardiopulmonary exercise testing. Am J Respir Crit Care Med. 2003;167(2):211-77.

24 Macintyre N, Crapo RO, Viegi G, Johnson DC, van der Grinten CP, Brusasco V, et al. Standardisation of the single-breath determination of carbon monoxide uptake in the lung. Eur Respir J. 2005;26(4):720-35.

25 Miller MR, Hankinson J, Brusasco V, Burgos F, Casaburi R, Coates A, et al. Standardisation of spirometry. Eur Respir J. 2005;26(2):319-38.

26 Spruit MA, Pennings HJ, Janssen PP, Does JD, Scroyen S, Akkermans MA, et al. Extrapulmonary features in COPD patients entering rehabilitation after stratification for MRC dyspnea grade. Respir Med. 2007;101(12):2454-63.

27 Lamers RJS, Wouters EFM, Kemerink GJ. Emphysema and airflow limitation in patients with advanced chronic obstructive pulmonary disease: a CT study. PhD Thesis (chapter 8) 1994.

28 Gosker HR, Lencer NH, Franssen FM, van der Vusse GJ, Wouters EF, Schols AM. Striking similarities in systemic factors contributing to decreased exercise capacity in patients with severe chronic heart failure or COPD. Chest. 2003;123(5):1416-24.

29 Ades PA, Savage PD, Brawner CA, Lyon CE, Ehrman JK, Bunn JY, et al. Aerobic capacity in patients entering cardiac rehabilitation. Circulation. 2006;113(23):2706-12.

30 Toth MJ, Gardner AW, Ades PA, Poehlman ET. Contribution of body composition and physical activity to age-related decline in peak V02 in men and women. J Appl Physiol. 1994;77(2):647-52.

31 Frontera WR, Suh D, Krivickas LS, Hughes VA, Goldstein R, Roubenoff R, et al. Skeletal muscle fiber quality in older men and women. Am J Physiol Cell Physiol. 2000;279(3):C611-8.

32 Debigaré $\mathrm{R}$, Côte $\mathrm{CH}$, Hould FS, LeBlanc $\mathrm{P}$, Maltais F. In vitro and in vivo contractile properties of the vastus lateralis muscle in males with COPD. Eur Respir J. 2003;21(2):273-8

33 Gosker HR, Hesselink MK, Duimel H, Ward KA, Schols AM. Reduced mitochondrial density in the vastus lateralis muscle of patients with COPD. Eur Respir J. 2007;30(1):73-9.

34 Rabinovich RA, Bastos R, Ardite E, Llinas L, Orozco-Levi M, Gea J, et al. Mitochondrial dysfunction in COPD patients with low body mass index. Eur Respir J. 2006;29(4):643-50.

35 Maltais F, LeBlanc P, Whittom F, Simard C, Marquis K, Belanger M, et al. Oxidative enzyme activities of the vastus lateralis muscle and the functional status in patients with COPD. Thorax. 2000;55(10):848-53.

36 Baarends EM, Schols AM, Akkermans MA, Wouters EF. Decreased mechanical efficiency in clinically stable patients with COPD. Thorax. 1997;52(11):981-6.

37 Gosker HR, Zeegers MP, Wouters EF, Schols AM. Muscle fibre type shifting in the vastus lateralis of patients with COPD is associated with disease severity: a systematic review and meta-analysis. Thorax. 2007;62(11):944-9.

38 Hansen MJ, Gualano RC, Bozinovski S, Vlahos R, Anderson GP. Therapeutic prospects to treat skeletal muscle wasting in COPD (chronic obstructive lung disease). Pharmacol Ther. 2006;109(1-2):162-72.

39 Amann M, Regan MS, Kobitary M, Eldridge MW, Boutellier V, Pegelow DF, et al. Impact of pulmonary system limitations on locomotor muscle fatigue in patients with COPD. Am J Physiol Regul Integr Comp Physiol. 2010;299(1):R314-24.

40 Pitta F, Troosters T, Spruit MA, Probst VS, Decramer M, Gosselink R, et al. Characteristics of physical activities in daily life in chronic obstructive pulmonary disease. Am J Respir Crit Care Med. 2005;171(9):972-7.

41 Guccione AA, Felson DT, Anderson JJ, Anthony JM, Zhang Y, Wilson PW, et al. The effects of specific medical conditions on the functional limitations of elders in the Framingham Study. Am J Public Health. 1994;84(3):351-8. 